siderably higher than most market analysts had anticipated. Two factors contributed. The first was a widespread expectation among investors that genetic engineering is the cornerstone of a future billion dollar industry, and Genentech is the only one of half a dozen small research companies to have gone public.

The second factor was a recent change in the tax law which has helped to restimulate the supply of venture capital. In 1969, Congress introduced legislation raising the effective rate of tax on long-term capital gains from 25 per cent to 48 per cent.

Many investors moved from the stock market to tax shelters, one result being a virtual drying up of new high-technology firms in the mid-1970s. In response, Congress cut the long-term capital gains tax back to 28 per cent in 1978 , contributing significantly to the fact that the number of new companies is increasing rapidly again.

Thus, despite recent government warnings about declining investment in technological innovations, there was no shortage of bidders for other Genentech stock. Many brokerage houses were unable to obtain any shares at all in the initial allocation; others who had requested 50,000 or more only received a few hundred.

At the same time, federal officials have taken steps to try to prevent the shares from being oversold, frightened that a backlash could cause investment capital to dry up again. Thus the public offer of the Genentech shares was held up for several days, apparently after a ruling from the Securities and Exchange Commission that more details about the company's operations should be made public.

A revised prospectus issued by the company revealed that in the first half of 1980 , Genentech had a revenue of $\$ 3.8$ million, of which most came from research contracts, and earnings totalled only $\$ 80,000$. Almost two-thirds of the contracts came from three pharmaceutical companies - A.G. Kabi of Sweden, Eli Lilly and Hoffman La Roche - with whom Genentech is working on human growth hormone, insulin and interferon respectively. The prospectus also revealed that the three companies will not be required to pay any royalties to Genentech after their research agreements expire. Although the agreements are described as "long-term", no further details are given.

Although several Wall Street analysts have claimed that the enthusiasm for the Genentech shares showed that the stock market was reviving, others added notes of caution. Half-way through the first day of trading, shares dropped from $\$ 80$ to $\$ 74$ following warnings from a senior partner of a major investment house that the explosive activity might be a "danger signal" and that "it will attract issues of lesser quality where an attempt will be made to create the same aura of scarcity".

David Dickson

\section{European universities}

European universities seem uniformly to be heading for demographic trouble. According to a 15-nation study commissioned by the European Science Foundation (ESF), European universities have too many academics in the younger age groups and consequently too small a rate of recruitment to university staffs. To make things worse, there is a prospect of falling student numbers as a consequence of low birthrates since 1970 .

The report urges "concrete corrective action" to avoid an "irreparable" loss of research talent in the immediate future and, in the longer run, a shortage of trained scientists for the economy. The rate of new recruitment to most university teaching and research staffs is estimated at less then half the 3 per cent per annum required to maintain a flat age distribution.

The decline of the European birthrate since 1970 is potentially a political threat to the universities. The report points out that unless a greater proportion of the age group elects for university education, enrolments will fall, teacher-student ratios will rise and governments will be tempted to cut university budgets.

Superficially, France may be the most seriously affected, with the most unbalanced age distribution among present academic staffs (see graphs). In 1977, 46 per cent of French uiniversity teaching staffs were aged $30-40$, and retirement rates will average only 1.3 per cent a year over the next five years. But France is also among the most active in correcting the problem. In 1975, the Centre National de la Recherche Scientifique set itself a target of creating 3 per cent new posts a year within a staff of some 8,000 researchers. After a shaky start in 1978-79, recruitment seems likely to rise once more to 3 per cent, with consequent benefits for mobility among scientists.

Switzerland is at the other end of the spectrum. Retirements from the universities generate a 2.3 per cent annual demand for replacements in 1981-85, and thereafter more than 3 per cent.

In Germany, replacement demand is estimated at 1.5 per cent a year between now and 1985. The falling birthrate -

\section{No room below} down by 40 per cent in the period $1967-77$

- will be especially troublesome. The "Heisenberg scheme" introduced in 1978 to increase the academic pool by 1 per cent a year, leaves much to be desired. Pay is relatively poor, contracts terminate after 5 years and in any case the most able get the few professorships on offer and leave the scheme.

Stock of permanent academic staff universities in seven European cou.

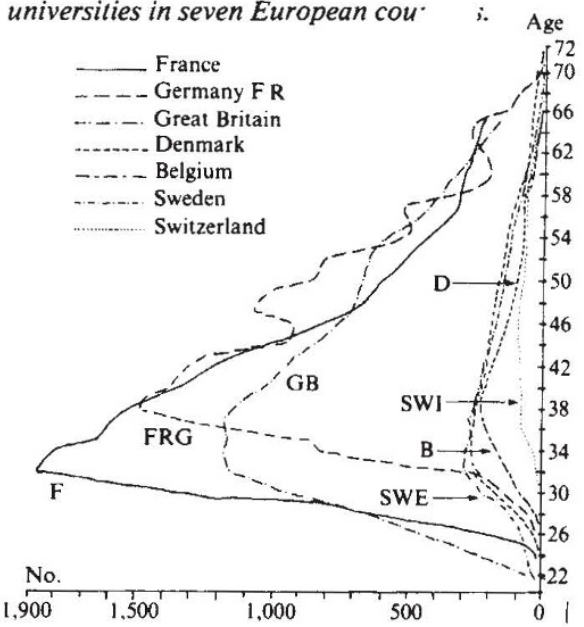

In the United Kingdom, the annual replacement rate is expected to be around 1.6 per cent, not reaching 3 per cent until the end of the century. Some 54 per cent of UK university staffs are between 30 and $\mathbf{4 5}$ years old. But, like France, the United Kingdom - and particularly the Science Research Council - has been at pains to do something about it. This year, the SRC is expected to make available 15 "Special Release Fellowships", which will pay professional salaries to senior academics often burdened by administration - to return to full-time research, while the monies thus released to the university will be used to employ a larger number of young researchers.

Of other countries studied, Belgium is in a particularly difficult position: 43 per cent of its university scientific staff are on shortterm contracts (compared with 61 per cent in government research institutions) and the majority of these are under 30 years old. Replacement demand for permanent positions is around 2 per cent, higher than most countries, but ESF has discovered no existing schemes in Belgium to tackle scientific unemployment. Denmark, with similar problems to most other countries, has proposals but no action; and Sweden,

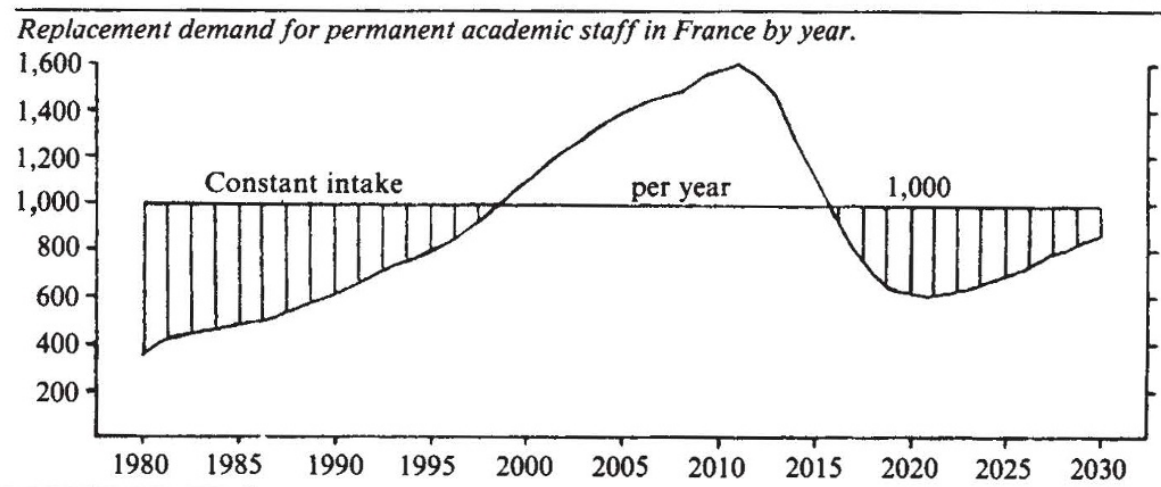


Norway and Austria provided no information to ESF about the measures they were undertaking.

The net result must be a fair degree of pessimism about the future of academic employment in Europe. The report makes 19 recommendations, few of them novel. The report also makes it plain that scientific mobility is also very low in Europe compared with the United States. Anxiety about jobs seems to have kept people at home. In the United Kingdom, for example, successful applications for the Royal Society European Fellowship exchange scheme fell from 91 in 1976 to 61 in 1979 (although the reverse traffic has kept up at about 90). $\quad$ Robert Walgate

\section{Carcinogen regulations}

\section{US labs exempt}

\section{Washington}

Following protests from both university and industrial scientists, the Department of Labor's Occupational Safety and Health Administration (OSHA) seems to be softening its stand on the control of toxic substances in research laboratories. Until recently, OSHA had been insisting that laboratories should be treated no differently from other workplaces in which individuals are occupationally exposed to hazardous substances.

A case in point is OSHA's new cancer policy, which was introduced at the beginning of this year: once a substance has been classed as a carcinogen based on defined scientific criteria, measures must be taken to reduce exposure levels to the lowest that is technologically feasible and eliminate them if possible.

Labour unions have supported OSHA's argument in the past that laboratories cannot be considered any safer than factory environments, and that the same regulations should therefore be applied to both. Union of ficials point to reports in the scientific literature which suggest that laboratory workers may be at increased risk with respect to carcinogens, and that cancer rates are high among certain professions, particularly chemists.

University scientists, however, have complained that regulations designed to reduce exposure to chemicals in an industrial environment may be inappropriate and unnecessarily expensive when applied to research laboratories using the same substance.

Additional problems arise from the fact that laboratory work may involve exposure to small quantities of many different chemicals, and that some of these might be difficult to subject to rigid classification.

Although OSHA's new cancer policy received much comment from the chemical industry when it was first proposed, little was heard from the scientific community until the public review process was well under way. (Many laboratories were unaware of the proposals' application to them.) As a result, when the revised policy was published in January, no specific attempt was made by the agency to exempt research laboratories from its scope. In a preamble to the policy, however, OSHA said that consideration would be given to setting separate standards for laboratories.

Now, under growing pressure from various agencies, including the National Science Foundation (NSF) and the Office of Science and Technology Policy (OSTP), the agency has begun to explore ways of moving in this direction. OSHA officials are working on a proposal, due to be published sometime in the new year, setting out possible procedures for the control of toxic substances in laboratories.

Their proposals are likely to conform closely to the recommendations of the ad hoc committee set up by the National Research Council of the National Academy of Sciences (NAS) to look at possible alternatives to the original OSHA cancer proposals as well as other aspects of handling toxic substances. Publication of the committee's report is expected soon.

The committee, initially financed by the American Chemical Society, the Alfred P. Sloan Foundation and the Manufacturing Chemists Association, with later federal support from the NSF, the National Institutes of Health (NIH) and the Environmental Protection Agency, is expected to propose that emphasis be given to developing general laboratory safety regulations rather than the substance-bysubstance regulations favoured by OSHA for industrial settings. The committee has in particular been keen to explore approaches which would be more flexible and less costly than those required under OSHA's present regulations.

Also due for publication in the near future are new guidelines that have been prepared by NIH covering the use of potential carcinogens in in-house laboratories. According to $\mathrm{Dr}$ Emmet Barkley, director of NIH's new Office of Research Safety, the guidelines (which include provisions for safety plans and medical surveillance) would be triggered whenever either OSHA regulates a chemical or an institute determines that a chemical is a carcinogen.

NIH's guidelines could be used as a model for other research laboratories, if OSHA sticks to a substance-by-substance form of control. However if - as seems more likely - greater emphasis is p'aced on general laboratory safety guidelines, the NAS report would probably provide the starting point, since this strategy would be a major departure for OSHA.

Another idea on which OSHA is thinking of asking for public comment is the setting up of an advisory committee to comment specifically on the safety measures required in research laboratories. More controversial is likely to be the role played by labour unions, which have been minimally involved in negotiations so far.

David Dickson

\section{Nobel prizes}

The Nobel Foundation has in the past two weeks announced in Stockholm the names of the recipients of Nobel Prizes as follows:

\section{Chemistry}

Dr Frederick Sanger (MRC Laboratory for Molecular Biology, Cambridge, UK) for the development of a technique for obtaining nucleic acid molecules.

Dr Walter Gilbert (Harvard University, Cambridge, USA) for the development of a different technique for obtaining the sequence of nucleic acid molecules.

Professor Paul Berg (Stanford University, California) for "research in nucleic acids and genetic manipulation".

The Sanger and Gilbert techniques have turned out to be complementary. Sanger uses a single DNA strand to synthesize random lengths of complementary DNA; Gilbert's technique entails the degradation of single strands of DNA in such a way as to generate a mixture of random polynucleotides always including some fixed recognition point.

Professor Berg is known to have been the first to use naturally occurring enzymes to synthesize composite DNA molecules in which two pieces of natural DNA were spliced together.

\section{Medicine and physiology}

The prize, which is shared three ways, wa: awarded for different aspects of ths research leading to present understanding of the human histocompatibility gene system (HLA). The recipients are:

Dr George Snell (Jackson Laboratory, Bar Harbor, Maine), responsible for the recognition of the mouse analogue of the HLA system, known as $\mathrm{H} 2$, and for the development of appropriate strains of inbred mice.

Professor Jean Dausset, (University of Paris) whose chief contribution was the recognition of the human histocompatibility antigens.

Professor Baruj Benacerraf (an Argentinian working at Harvard University) was chiefly responsible for the identification of the system of genes responsible for the HLA antigens.

\section{Physics}

The 1980 physics prize has been awarded for the discovery of what is called " $\mathrm{CP}$ violation" to Professor J.W. Cronin (Chicago University) and Professor Val Fitch (Princetown University).

Their discovery was the experimental observation of the decay of a neutral meson into two charged pions (Phys. Rev. Lett. 13, 138; 1964). The outcome was the recognition that in the interactions or spontaneous transformations of elementary particles, parity (left or right-handed geometrical symmetry) need not be conserved. 